\title{
The Potential Of Financial Technology Towards To Stimulate Startup In Indonesia: Peer-To-Peer Lending Scheme
}

\author{
Alfiandi Imam Mawardi ${ }^{1}$, Reiga Ritomiea Ariescy ${ }^{2}$, Luky Susilowati ${ }^{3}$, Pandji Soegiono ${ }^{4}$ and \\ Supriyono $^{5}$ \\ \{alfiandi.ma@upnjatim.ac.id $\left.{ }^{1}\right\}$ \\ 1,2,3,4,5 Economy and Business Faculty, Universitas Pembangunan "Veteran” Jawa Timur, Indonesia
}

\begin{abstract}
With the 4.0 industrial revolutions, which used technology and internet as the main driving force for the economy development, it revolutionized economic conditions in every side of the world. The existence and application of the use of financial technology in Indonesia must also continue to be developed, and also massive use of financial technology will create new opportunity for startup in Indonesia. This research will discussed about development of financial inclusive and peer-to-peer lending scheme toward stimulate Indonesia startups. This descriptive research also to examine financial technology factors that should be improve and be mitigate any appearing risks. The study findings provide managerial implications and theoretical contributions.
\end{abstract}

Keywords: Financial Technology, Financial Inclusion, Peer-To-Peer Lending Scheme, Startup

\section{Introduction}

There has been a shift in the digital direction, which financial institutions has been challenged to make great transformations. Financial services have begun to innovate to abandon inefficient on conventional systems in this digital era. Changes in the pattern of financial service consumers who have efficient mindset will become a security for conventional financial institution. Financial institutions began to collaborate between financial services with devices and internet connection that known as financial technology. Recently, financial innovations has been driven by technological advancement (financial technology) are reflected in some platforms such as digital (mobile and internet) payments, electronic money, crowd funding, peer-to-peer lending, investment, financial aggregator, and financial advisor. In here, we focus on online direct (peer-to-peer/P2P) lending which could directly help improve access to financing for startup in small or medium scale of business. P2P lending platforms facilitate direct lending from surplus spending units to deficit spending units in an online system [1].

According to data in September 2018, 67 platforms have been registered in Otoritas Jasa Keuangan (OJK). Moreover, the loans have been more than IDR 9 trillion (USD 600 million), with the average yearly growth is more $300 \%$. The number of borrowers has been more than 1.4 million accounts while total lenders are more than 135 thousand accounts. Moreover, the growing need of access to financing from Startup or SMEs with low access to banks creates a large opportunity to P2P to grow even further. Thus, it is necessary to ensure consumer 
protection both for the borrowers and lenders regarding the safety of the transaction and investment and reducing fraud.

Table 1. Growths of P2P Lending Users

\begin{tabular}{cccc}
\hline No & Description & October 2018 & October 2019 \\
\hline $1 . \quad$ Total Lender Account (Account) & & \\
a. Java & 138.509 & 477.742 \\
b. Out of Java & 42.484 & 96.779 \\
c. Foreign & 1.902 & 3.637 \\
d. Total & 182.895 & 578.158 \\
2. $\quad$ Total Borrower Account (Entity) & 2.389 .765 & 13.326 .505 \\
a. Java & 415.261 & 2.660 .218 \\
b. Out of Java & 2.805 .026 & 15.986 .723 \\
c. Total & & \\
3. Total Lending Accumulation (Rp) & a. Java & 13.692 .089 .578 .312 & 58.299 .150 .146 .730 \\
& b. Out of Java & 2.298 .053 .563 .043 & 9.700 .729 .924 .590 \\
d. Total & 15.990 .143 .141 .355 & 67.999 .880 .071 .319
\end{tabular}

Source: Processed

Based on that table 1.1 shows the portfolio is channeling funds through the peer to peer (P2P) lending scheme as of October 2019 it has reached IDR 58.2 trillion which is rapidly increased by IDR 45 trillion of P2P Lending Accumulation from 2018 to 2019. In Indonesia, the types of SME or Startup have great potential to create inclusive development because besides being the biggest contributor to Gross Domestic Product (GDP), this type of business will open many jobs. However, these inclusive development opportunities are hampered by the lack of access to finance by financial institutions for SMEs [2]. The types of SMEs are dominated by startups, so that they often experience financial ups and downs that are not yet stable. The limited capital ownership of SMEs makes it necessary for loan assistance to maintain the sustainability of their businesses. In 2013, the amount of credit extended to SME was IDR 639.47 trillion and in 2014 the number increased to IDR 767.57 trillion or 20 percent from the previous year. The amount of credit extended by banking continues to increase until 2017 reaching IDR 935.44 trillion. Moreover, Startup lending in the second semester of 2016 reached IDR 857 trillion or $19.4 \%$ of the total bank lending. Loan portfolio grew by $8.4 \%$, an increase compared to the previous semester of $8.3 \%$ and compared to the previous year, which was $8 \%$. The increase in SME or Startup credit growth is one indicator of the economic recovery on domestic economic slowdown in previous years. The condition of banking liquidity and the continued decline in lending rates helped drive SME credit growth at the end of 2016 [3].

The purpose of this study is to analyze the potential of financial technology that has developed in Indonesia from factors that influence its development and the risks that can arise. This study also has two research questions, there are how is potential financial technology in Indonesia according to P2P lending scheme and what are P2P lending scheme risks. 


\section{Research Methods}

This research uses descriptive studies approach that analyzes financial technology development from financial inclusive especially in P2P lending. The data obtained in this study are secondary data in the form of journals, books and other data from researches [4] .

\section{Result and Discussion}

As a result of the digitalization of finance, the application of technology has also changed the credit service system to improve the efficiency of financial transactions. An accessible Internet everywhere will expand financial access, open information, eliminate the role of intermediaries and can reduce operational costs.

\subsection{Potential of P2P Lending Scheme in Financial Inclusion}

There are great opportunities for creating inclusive development in Indonesia's SME, but on the other hand the existence of obstacles in credit financing led to a loan innovation with a peer to peer lending ( $\mathrm{P} 2 \mathrm{P}$ lending) scheme. This scheme can bring together borrowers and lenders in an easy, fast and safe manner. In 2006, the peer-to-peer lending (P2P) scheme has first emerged in the UK and followed by the United States and China. Although China is not the first country to start this peer-to-peer lending scheme, it is a country that has a very large market share compared to the United States and Britain. It can be seen that there is quite a comparison between China, which has a market size of US \$150 B, while the United Kingdom and the United States each amounted to US \$ 4 B and US \$ 12 B (.

Indonesia needs to learn from China that has succeeded in establishing such a scheme in large and fast numbers. The thing that makes China have the biggest market size is because of the large number of SMEs there and the need for huge loan assistance. In addition, the funders are also confident to provide loans to China because the types of SME there have a good track record of competitiveness, proven that various products have entered the global market. By capitalizing the internet with a device it can be an online meeting between lenders or investors and borrowers or as a company that brings lenders together with loan seekers can become a scheme to reduce the gap or distance of funding needs for SME or entrepreneurs.

According to Otoritas Jasa Keuangan (OJK), the financial inclusion index national scale has increased from year to year. In 2013 and 2016 the 59.74 percent and 67.82 percent respectively, while in 2017 the inclusion financial index increased compared to the previous year reaching 69 percent of the population. That is because the digitalization of financial services began to be accessed by society is increasingly improving. This peer to peer (P2P) invoicing has a multiplier effect to create inclusive development. Proved that according to Oxford Economics studies every 1 percent, the penetration of mobile devices will increase gross domestic product (GDP) by as much USD 640 million by 2020 and creating 10,700 formal workers. Research released by the World Bank if there is an increase in financial inclusion system facilities by 1 percent could increase GDP per capita growth by 0.03 percent. If the Government of Indonesia and the greater community to support digital penetration of financial services not only increase GDP, but will increase economic development in Indonesia because it can open new jobs [5]. 
The peer-to-peer (P2P) lending scheme is very beneficial for fund borrowers namely the SMEs. In addition to access that is easier and faster than banking, this scheme nor does it burden SMEs because the interest is relatively small compared to banks. The growth of online-based massages is quite rapid in Indonesia because of this investors see this loan scheme as more profitable and minimally risky. When banking has a non-performing loan ratio in February 2018 of 2.88 percent, but if compared to peer to peer lending schemes having a risk of bad credit is only 0.64 percent [6].

Because of this scheme, one person can only fund 20 percent of total funding as a form of risk diversification. With the limitation of funding this will minimize the risk of default is quite large because the loss will be borne along with the parties another lender. In this loan scheme investors can get to know borrowers of funds openly as a form of risk transparency and is free to choose the category of risk credit scoring you want fund, If the higher the risk, the higher the interest to be paid. Peer-to-peer lending (P2P) schemes are very beneficial for borrowers of funds namely the SMEs. In addition to access that is easier and faster than banking, this scheme nor does it burden SMEs because the interest is relatively small compared to banks. When banking has a non-performing loan ratio in February 2018 of 2.88 percent, but if compared to peer-to-peer lending schemes having a risk of bad credit is only 0.64 percent. Because of this scheme, one person can only fund 20 percent of total funding as a form of risk diversification. With the limitation of funding this will minimize the risk of default is quite large because the loss will be borne along with the parties another lender [7]. In this loan scheme investors can get to know borrowers of funds openly as a form of risk transparency and is free to choose the category of risk credit scoring you want fund, If the higher the risk, the higher the interest to be paid.

\subsection{Financial Risk in P2P Lending Scheme}

There are some risks that can indeed be a problem for P2 Lending, namely the credibility of loan service providers, security issues, payment delays and defaults. The credibility of this loan service provider is the risk of branding from a financial technology where they must be able to build investor confidence about the services they create. Financial inclusion is an answer that can be maximized supported by government assistance through the FSA to encourage the investment climate and supervision of reasonable and licensed financing. Then the issue of security is a matter of concern that is very important to be maintained. Digital systems always have gaps and are easy to pin down, just like systems that already exist in conventional banks. Digital security systems become a very serious risk when P2P lending systems do not have very sophisticated security systems [3].

Payment delays are what can happen to the P2P Lending scheme because the average investment turnover is in the SME sector, which is a high-risk investment instrument and does not have good financial management. It is different from investment instruments in stocks and bonds that are indeed invested in companies that have adopted GCG and good transparency. The highest risk when there is default from the promised interest. This risk is inherent in this investment instrument due to problems of financial institutions and their investment objects. This should be the concern of all relevant stakeholders, especially the government represented by the FSA. OJK must monitor all P2P lending activities that indicate it will cause problems, that is not only reactive but also preventive action is the best action that must be taken. 


\section{Conclusion}

Financial technology is a new phenomenon in the financial world in Indonesia, with the higher digital and financial literacy the higher their chances of growth. P2P lending, which is part of financial technology, must be able to help SMEs who are having difficulty getting financial access from banks. This unbankable sector is a sector that is constantly being looked at by investors with all the risks attached to it, besides that SMEs must be able to professionally grasp this opportunity. The government as a regulator must be able to maintain the investment climate and the development of P2P lending towards a more professional, safe and efficient manner. This can be done by providing professional supervision, careful policy and providing financial access for new startup.

\section{Reference}

[1] PwC Indonesia, “Indonesia's Fintech Lending :," no. June, 2019.

[2] 2018) Accounting Competition, Call for Essay and Strategic Seminar 2018 (ACCESS, "The Transformative Power of Fintech," Transform. Power Fintech, p. 21, 2018.

[3] W. Santoso, I. Trinugroho, and T. Risfandy, "What Determine Loan Rate and Default Status in Financial Technology Online Direct Lending? Evidence from Indonesia," Emerg. Mark. Financ. Trade, no. December, 2019.

[4] H. K. Mohajan, "M P RA Munich Personal RePEc Archive Qualitative Research Methodology in Social Sciences and Related Subjects Qualitative Research Methodology in Social Sciences and Related Subjects," UTC J. Econ. Dev. Environ. People, vol. 85654, no. 85654, p. 1, 2018.

[5] A. U. Djawahir, "Teknologi-layanan Keuangan, Literasi-inklusi Keuangan, dan Value pada Fintech Syariah di Indonesia: Perspektif S-O-R (Stimulus-organism-response) Model," 2nd Proc. Annu. Conf. Muslim Sch., no. April 2018, pp. 439-448, 2018.

[6] M. C. M. Evy Nur Sugiarti, Nur Diana, "Peran Fintech Dalam Meningkatkan Literasi Keuangan Pada Usaha Mikro Kecil Menengah Di Malang,” E-Jra, vol. 08, no. 4, pp. 90-104, 2019.

[7] T. D. Uyen and H. Ha, "the Sharing Economy and Collaborative Finance: the Case of P2P Lending in Vietnam,” J. Ilm. Ekon. Bisnis, vol. 22, no. 2, pp. 84-93, 2017. 